and other legal acts of the European Union in the national legislation of the countries that are at a later stage of EU integration (Albania, Serbia, Montenegro, Macedonia, Kosovo, etc.) is analyzed.

Key words: EU Directive, EU Regulation, implementation, categories of weapons, harmonization of legislation.

DOI: 10.33766/2524-0323.88.157-165

УДК 343.121.5

Д. В. Шилін,

кандидат юридичних наук, доцент, доцент кафедри кримінального процесу

Національного університету

«Одеська юридична академія»

(м. Одеса, Україна)

e-mail: S_D_V@ukr.net

(Dhttps:// orcid.org/0000-0002-8990-3534

\title{
ЗАГАЛЬНІ ПИТАННЯ ВИКОРИСТАННЯ ПРЕЮДИЦІЇ В КРИМІНАЛЬНОМУ ПРОВАДЖЕННІ
}

Стаття присвячена дослідженню питань, пов'язаних із межами використання преюдиції в кримінальному провадженні, а також визначенню шляхів удосконалення механізму використання преюдищії в кримінальному провадженні та вирішенню спірних ситуацій, які виникають при використанні преюдицій у кримінальному процесі. Розкрито механізм дії преюдицій у кримінальному процесі. Визначено напрями вирішення преюдищіальних колізій при провадженні в кримінальній справі.

Ключові слова: преюдиція, доказування в кримінальному процесі, преюдиціальність, юридичні факти, обов'язковість судових рішень.

Постановка проблеми. Забезпечення функціонування правосуддя є одним із найголовніших пріоритетів сучасної держави. При цьому завантаженість суддів та складність виконання їх повноважень значно обтяжує поставлене завдання. Для полегшення здійснення судочинства 3 метою забезпечення виконання рішень судів з урахуванням положення ч. 2 ст. 13 Закону України «Про судоустрій та статус судів», згідно з якою обов' язковість урахування (преюдиційність) судових рішень для інших судів визначається законом [4], у кримінальному провадженні активно застосовуються преюдиції.

Проте преюдиції, незважаючи на свою основну роль, викликають чимало суперечностей при застосуванні їх під час вирішення справ кримінальної юрисдикції. Саме тому розгляд значення рішень інших судів для суду, який здійснює правосуддя в межах кримінального провадження, являє собою вагомий теоретичний вклад у науку, який у подальшому може набути практичного застосування.

Аналіз останніх досліджень і публікацій. Дослідженню зазначених питань присвячена велика кількість наукових праць вітчизняних та зарубіжних теоретиків, серед яких А. М. Безруков, О. І. Бережний, О. Ю. Гай, Ю. М. Грошевий,

(с) Шилін Д. В., 2019 
О. В. Левченко, В. Т. Маляренко, Я. О. Мотовіловкер, І. Л. Петрухін, Г. М. Резнік, П. А. Скобліков, С. М. Стахівський, М. С. Строгович, Ф. Н. Фаткуллін, О. 3. Хотинська, В. Д. Шундіков, У. М. Юсубова. При цьому ступінь дослідженості теми все ще дозволяє продовжувати вивчення преюдищій у кримінальному провадженні.

Формування цілей. Метою цієї статті є дослідження значення та доцільність застосування рішень інших судів для суду, який вирішує справу по суті в межах кримінального провадження.

Для досягнення встановленої мети були поставлені такі завдання:

- охарактеризувати поняття преюдицій та їх роль при здійсненні правосуддя;

- проаналізувати закріплення преюдицій у кримінальному процесуальному законодавстві України;

- визначити межі застосування рішень суду, якими встановлено преюдиційний факт.

Виклад основного матеріалу. Виконання завдань кримінального провадження неможливе без процесу доказування, який, відповідно до ч. 2 ст. 91 Кримінального процесуального кодексу України (далі - КПК України), являє собою збирання, перевірку та оцінку доказів з метою встановлення обставин, що мають значення для кримінального провадження [3]. Доказування - складний процес, який обумовлюється предметом доказування та здійснюється в межах чіткої регламентації з боку кримінального процесуального законодавства 3 дотриманням основних вимог до доказів, а саме їх належності, допустимості та достовірності.

Допустимість доказів, що, відповідно до ч. 1 ст. 86 КПК України, являє собою дотримання порядку, передбаченого КПК, у процесі отримання доказів [3], яК категорія кримінального процесуального права, донині викликає чимало питань теоретичного та практичного характеру. Досить неоднозначним є тлумачення та застосування преюдиції в кримінальному провадженні.

У юридичній літературі існують різні підходи до визначення поняття преюдиції. У межах загальної теорії права вона розглядається як прийом юридичної техніки. Так А. В. Карданець визначає преюдицію як прийом юридичної техніки, що являє собою правило доказування про те, що правозастосовче рішення уповноваженого органу, яке набрало законної сили, прийняте у встановленому законом процесуальному порядку про наявність або відсутність юридичного факту, обов'язкове для всіх правозастосовчих органів, які вирішують юридичну справу, пов'язану із раніше вирішеною з приводу цього факту [7, с. 30]. Віддаючи належне цьому визначенню преюдиції як прийому юридичної техніки, що правильно відбиває ії правову природу, слід зазначити, що системний підхід до дослідження правових преюдицій дозволяє говорити про це явище як про загальноприйняте теоретичне положення, яке $є$ надбанням професійної правосвідомості та яке містить в усіх компонентах правової системи [9, с. 209]. Окремі вчені пропонують визначати поняття «преюдиція» як передсудимість (передрішення), сутність якої полягає в тому, що закон встановлює визначене коло справ, які обов'язково припускають 
попередній розгляд деяких пов'язаних із ними питань іншими органами та, у першу чергу, цивільними судами. Усі подібні постанови мають те значення, що для суду, який розбирає справу, попереднє рішення іншого суду з питання, пов'язаного із справою, що розглядається, має значення істини та приймається без будь-яких доказів [1, с. 97; 5, с. 83; 6, с. 117; 11, с. 217-218; 12, с. 58].

Преюдицією або преюдиційним фактом є встановлені судом факти, достовірність яких вважається доведеною для всіх судів у межах будь-якого іншого, у тому числі кримінального провадження. Таким чином, виконуються одразу дві вимоги до доказу, а саме його достовірність та допустимість.

Основними ознакам преюдиції слід вважати:

1) обов' язковість застосування, яка закріплена правовими нормами;

2) достовірність фактів та / або обставин, встановлених преюдицією;

3) зв'язок обставин справи, що розглядається, із судовим рішенням, що набрало законної сили.

Процесуальна роль преюдиції виявляється в процесуальній економії, оскільки дає змогу використовувати встановлені попередньо факти та обставини, не здійснюючи повторно всі стадії доказування. Так подія кримінального правопорушення, яка раніше була доведена оглядом місця події, показаннями свідків, потерпілих тощо і закріплена рішенням суду, не підлягає встановленню в межах іншого провадження, незважаючи на те, що ця подія входить до предмету доказування. Процесуальну економію слід розцінювати як «побіжну» перевагу, яка досягається при реалізації преюдицій, коли між преюдиціальними фактами та пов' язаними з ними матеріалами провадження в іншій кримінальній справі не виникає протиріч [3, с. 58-59].

На думку автора, значення преюдиції полягає ще й у підвищенні відповідальності суддів, оскільки сприяє винесенню законних та обгрунтованих рішень, які стосуються не тільки прав та інтересів сторін конкретної справи, а в подальшому можуть вплинути на дотримання прав та інтересів інших осіб, яке залежить від фактів, що встановлені в цьому рішенні. Таким чином, преюдиція спонукає суддів приймати рішення, які $є$ належним чином мотивовані та характеризуються ясністю, чіткістю, переконливістю викладених аргументів у мотивувальній та резолютивній частинах рішення.

Преюдиція в кримінальному процесі закріплена ст. 90 КПК України, згідно 3 якою рішення національного суду або міжнародної судової установи, яке набрало законної сили і ним встановлено порушення прав людини й основоположних свобод, гарантованих Конституцією України і міжнародними договорами, згода на обов'язковість яких надана Верховною Радою України, має преюдиціальне значення для суду, який вирішує питання про допустимість доказів [3].

Аналізуючи вищевказане, слід виділити умови преюдиційності рішення.

По-перше, мова йде про рішення національних судів або міжнародних судових установ. Слід звернути увагу, що законодавець позбавляє рішення суду іноземних держав привілею встановлення преюдиції. Незважаючи на визнання та виконання вироку іноземної держави, передбачені ч. 1 ст. 602 КПК України, преюдиційний факт ним встановлюватися не може, оскільки в основі преюдиційності лежить дотримання процедури доказування, яка чітко 
регламентована законодавчими актами. Оскільки процес доказування, регламентований іноземними державами, може відрізнятися від вимог, передбачених українським процесуальним законодавством, встановлення преюдиції в такому вироку слід розглядати як порушення процесуальних норм.

До того ж не зазначається й галузева приналежність суду. Так преюдиційне значення мають рішення судів, винесені при вирішенні справ у межах кримінального, цивільного, господарського та адміністративного проваджень.

На думку автора, упущенням законодавця є надання преюдиційності рішенням міжнародної судової установи без конкретизації того факту, що юрисдикція такої міжнародної судової установи повинна бути визнана Україною у встановленому порядку. Так на даному етапі розвитку міжнародних відносин, аналізуючи підписані та ратифіковані Україною міжнародні договори судовими установами, юрисдикція яких визнана Україною, є Свропейський суд з прав людини, Міжнародний комерційний арбітражний суд та Міжнародний суд ООН. Таким чином, тільки рішення вищезазначених міжнародних судових органів повинні мати преюдиційне значення в межах здійснення правосуддя.

По-друге, основоположне значення має те, що рішення суду повинно вступити в законну силу, оскільки саме з цим моментом пов' язується виникнення правових наслідків та обов'язковість виконання рішень суду на всій території української держави. При цьому слід звернути увагу, що набрання рішенням законної сили не виключає можливості перегляду такого рішення в касаційній інстанщії, а також у зв' язку з нововиявленими або виключними обставинами в порядку, передбаченому українським процесуальним законодавством. Одним із наслідків перегляду рішення $є$ його скасування, що може призвести до недоведеності факту, який мав преюдиційне значення.

Третьою умовою преюдищійності рішення суду $є$ встановлення ним порушення прав людини й основоположних свобод. При цьому преюдищійність розповсюджується як на наявність факту чи обставини, так і на їх відсутність.

Слід звернути увагу, що ст. 90 КПК України встановлює преюдищійність рішення інших судів для суду, який вирішує питання про допустимість доказів. Однак, у процесі доказування бере участь не тільки суд, а й сторона обвинувачення, сторона захисту та потерпілий. Так, збираючи докази, проводячи ïх попередню оцінку, преюдиційність рішень суду для вказаних суб'єктів також має значення, оскільки вирішення питання щодо включення преюдиційних фактів до предмету доказування належить виключно суб' єкту доказування.

Дискусійним залишається питання встановлення меж преюдиційності рішень суду, тобто переліку тих фактів, які можуть бути встановлені іншим судом та використовуватися в кримінальному провадженні. Частина 1 ст. 91 КПК України встановлює перелік обставини, які підлягають доказуванню в кримінальному провадженні. Саме на цих обставинах грунтується предмет доказування. Проаналізувавши положення норми, автор схиляється до думки про можливість застосування рішень суду, якими встановлено преюдиційний факт, до всіх пунктів, крім другого, а саме щодо факту встановлення винуватості обвинуваченого у вчиненні кримінального правопорушення, форми вини, 
мотиву й мети вчинення кримінального правопорушення. Так суд може брати до уваги встановлені іншим судом наявність або відсутність певної події або факту, у жодному разі не даючи оцінку поведінці обвинуваченого як такої, що свідчить про наявність чи відсутність вини. Усі докази винуватості підлягають дослідженню в змагальному кримінальному провадженні з дотриманням права на захист у кожному конкретному випадку.

Найчастіше рішення інших судів беруться до уваги у справах, що стосуються співучасника стосовно фактів та правових висновків, встановлених у раніше винесеному рішенні щодо інших співучасників; у справах про дачу завідомо неправдивих показань, правових висновків, встановлених у раніше винесеному рішенні справи, у межах якої давалися показання свідка або висновок експерта; у кримінальній справі в межах перегляду судового рішення за нововиявленими обставинами тих рішень, якими ці обставини встановлено.

Незважаючи на те, що преюдиційні факти тісно пов'язані $з$ доказами, їх правова природа різна. Згідно 3 ч. 1 ст. 84 КПК України, доказами в кримінальному провадженні є фактичні дані, отримані в передбаченому цим Кодексом порядку, на підставі яких слідчий, прокурор, слідчий суддя і суд встановлюють наявність чи відсутність фактів та обставин, що мають значення для кримінального провадження та підлягають доказуванню [3]. Преюдиції, у свою чергу, являють собою вже встановлений факт чи обставину. Таким чином, преюдиція, встановлена рішенням суду, є наслідком доведеності доказом певного факту або обставини. Крім того, достовірність преюдиції може бути піддана сумніву в межах іншого провадження, ніж те, у якому іiі було встановлено, у той час як доказ оспорюється тільки в рамках провадження, у якому використовується під час доказування, оскільки доказ, на відмінну від преюдиції, $є$ належним та допустимим у кожному конкретному провадженні.

Незважаючи на вищевикладене, факти та обставини, встановлені іншим судом, проходять процес доказування з урахуванням певних особливостей. Так збирання доказів відносно преюдиції обмежується шляхом витребування рішення суду, у якому цю преюдиції визначено, або залученням до справи належним чином оформленої копії.

Перевірка може бути здійснена аналізом змісту рішення та встановленням його доказового значення для кримінального провадження. При цьому жодних обмежень щодо перевірки преюдищії законодавством не передбачається. Тобто в разі сумніву в достовірності преюдиції, суб'єкт доказування не позбавлений права здійснювати додаткові дії для ії підтвердження чи спростування.

Достатньо гостро стоїть питання співвідношення ролі суду в оцінщі доказів при винесені рішення й преюдиції, оскільки остання певним чином обмежує активну позищію суду. Так, відповідно до ч. 1 ст. 94 КПК України, слідчий, прокурор, слідчий суддя, суд за своїм внутрішнім переконанням, яке грунтується на всебічному, повному й неупередженому дослідженні всіх обставин кримінального провадження, керуючись законом, оцінюють кожний доказ із точки зору належності, допустимості, достовірності, а сукупність зібраних доказів - 3 точки зору достатності та взаємозв'язку для прийняття відповідного процесуального рішення [3]. Крім того, частиною другою цієї статті встановлено, 
що жоден доказ не має наперед встановленої сили. Однак, як було з’ясовано раніше, преюдиція не є доказом, тому й не суперечить указаній нормі.

У даній ситуації суб'єктивним критерієм для застосування преюдиції є ії співвідношення з внутрішнім переконання суб'єкта доказування, у першу чергу суду. Необхідним є розумний баланс між дотриманням правила про оцінку доказів за внутрішнім переконанням та збереженням значення преюдиції. Преюдиція в кримінальному процесі не несе характеру передвстановлених доказів, а правила використання преюдицій не можуть перебувати в суперечності з принципом оцінки доказів за внутрішнім переконанням. На думку О. І. Бережного, виникнення колізії між преюдицією і внутрішнім переконанням суду можливе в таких випадках: по-перше, коли під час провадження з кримінальної справи стосовно осіб, які брали участь у розгляді цивільної справи, суд ставить під сумнів правильність висновків про подію чи дії з цивільної справи. По-друге, колізія можлива й у випадках, коли при провадженні з кримінальної справи стосовно особи, яка має судимість, у суду з'являються сумніви щодо правильності правових висновків, зроблених у раніше винесеному судовому рішенні. I нарешті, по-третє, у разі, коли в суду, що розглядає питання про скасування раніше винесеного вироку за нововиявленими обставинами, з'являються сумніви в законності чи обгрунтованості вироку, що встановив ці обставини [1, с. 9-10].

Таким чином, для правильного застосування преюдиції необхідно встановити баланс між нею та внутрішнім переконанням суб'єкта доказування, який, наприклад, може бути виражений у встановленні законодавцем порядку спростування преюдиції, оскільки прямої заборони щодо оспорювання фактів, визнаних у рішенні суду, не встановлено. В українській правовій системі діє принцип правової визначеності, відповідно до якого рішення суду не повинні протиставлятися одне одному. Однак на практиці виникає дещо інша ситуація, тому необхідно на законодавчому рівні передбачити механізм розв'язання ситуації, коли суд виносить рішення в кримінальному провадженні, що суперечить рішенню, яке містить преюдиціальні факти. До того ж не виключеною $є$ можливість зловживанням правом, коли особа звертається до суду не з метою захисту своїх прав, а з метою впливу на суддю в кримінальному процесі шляхом пред'явлення рішення іншого суду, яким встановлено преюдиційний факт. Наприклад, рішенням суду цивільної юрисдикції може бути встановлено спільне проживання осіб, що матиме наслідком породження режиму спільної сумісної власності, яке ускладнюватиме розслідування факту недостовірного декларування, або ж судом у межах адміністративного судочинства може бути встановлено відсутність певних повноважень у конкретної посадової особи, що викличе сумнів у пред'явленому раніше обгрунтованому обвинуваченні щодо перевищення повноважень.

3 огляду на вищевказане, автор вважає, що рішення суду повинно мати преюдиційне значення тільки в тому випадку, коли встановлений факт не викликає сумнівів у жодної зі сторін конкретного кримінального провадження.

Прогалини в законодавчому регулюванні застосування преюдиції проявляються і на стадії перегляду судових рішень. Так у випадку, коли 
обвинувальний вирок стосується кількох осіб співучасників й апеляційний суд, не виходячи за межі апеляційної скарги, не знаходить обгрунтування прийняття рішення на користь осіб, щодо визнання винуватості яких не було подано апеляційної скарги, може виникнути два рішення, що встановлюють преюдицію: вирок суду першої інстанції, який скасовано частково, та рішення, яке проголошено в межах апеляційного перегляду.

Можливі в таких випадках ситуації появи суперечливих судових рішень (прийнятого на підставі внутрішнього переконання та існуючого преюдиціального) стосовно одних і тих же фактів пропонувалося вирішувати в такий спосіб: а) невинесення другого судового рішення, доки не буде скасовано преюдиціального; б) винесення вироку (судового рішення) за внутрішнім переконанням суду та внесення в закон указівки на те, що вирок, яким відкинуто преюдицію, не набирає законної сили доти, доки вищий суд не перевірить обох вироків і не вирішить питання, який із них правильний (варто зауважити, що такий підхід є домінуючим у юридичній літературі); в) зупинення судом провадження у справі та ініціювання перегляду за нововиявленими обставинами раніше винесеного вироку, яким неправильно встановлено преюдиціальні факти [2, с. 137].

Висновки. Аналізуючи вищевикладене, варто зробити висновок, що значення рішень суду, яким встановлено факт або обставину, не можна нівелювати при здійсненні судочинства в межах кримінальної юрисдикції, однак застосовувати преюдицію слід з урахуванням балансу між принципом обов'язковості судових рішень та принципом неупередженості та незалежності суду.

\section{Використані джерела:}

1. Арсеньев В. Д. О фактах, не подлежащих доказыванию в процессе уголовного судопроизводства / В. Д. Арсеньев // Правоведение. 1965. № 1. С. 97 - 104.

2. Бережний О. І. Преюдиціальність судових рішень у кримінальних справах: автореф. дис... канд. юрид. наук: 12.00 .09 / О. І. Бережний. Харків, 2003. 20 с.

3. Березин А. С. Преюдиции в отечественном уголовном судопроизводстве : дис.... кандидата юридических наук: 12.00.09. / Березин Александр Сергеевич. Нижний Новгород, 2006. 283 с.

4. Вапнярчук В. Сутність преюдиціальних фактів та їх значення для кримінально процесуального доказування. / В. Вапнярчук / / Публічне право. 2013. № 4 (12). С. 135-142.

5. Дорохов В.Я. Законная сила приговора в советском уголовном процессе / В. Я. Дорохов // Советское государство и право. 1954. № 6. С. 80-86.

6. Каминская В. И. Учение о правовых презумпциях в уголовном процессе / Каминская В. И. М-Л.: АН СССР, 1948. 131 с.

7. Карданец А. В. Преюдиции в российском праве. Проблемы теории и практики : дис. ... кандидат юридических наук: 12.00.01. / Карданец Артем Викторович. Нижний Новгород, 2002. 181 с.

8. Кримінальний процесуальний кодекс України від 13.04.2012 p.: URL: https://zakon.rada.gov.ua/laws/show/4651-17.

9. Попов С. В. К вопросу о системном подходе к исследованию правовых преюдиций / С. В. Попов / / Юридическая техника. 2007. №1. С. 208-210. 
10. Про судоустрій і статус суддів: Закон України від 02.06.2016 р. № 1402-VIII. URL: https:/ / zakon.rada.gov.ua/laws/show/1402-19

11. Строгович М. С. Учение о материальной истине в уголовном процессе / Строгович М. С. М.: АН СССР, 1947. 274 с.

12. Штутин Я. Л. Предрешения (преюдиции) в советском гражданском процессе / Я. Л. Мотовиловкер / / Советское государство и право. 1956. № 5. С. 58-67.

\section{References:}

1. Arsenyev, V. D. (1965) O faktah, ne podlezashih dokazyvaniyu v processe ugolovnogo proizvodstva. Pravovedenie- Jurisprudence, 1, 97-104. [in Russian].

2. Bereznoy, O. I. (2003) Preyudicialnist sudovyh rishen u krymynalnyh spravah. Extended abstract of candidate's thesis. Kharkiv. [in Ukrainian].

3. Berezin, A. S. (2006) Preyudicii v otechestvennom ugolovnom sudoproizvodstve. Candidate's thesis. Nizniy Novgorod. [in Russian].

4. Vapnyarchuk, V. (2013) Sutnist preyudicialnyh faktiv ta yih znachenya dlya krymynalno procesualnogo dokazuvanya. Publichne pravo - Public law, 4(12), 135-142. [in Ukrainian].

5. Dorohov, V. Y. (1954) Zakonnaya sila progovora v sovetskom ugolovnom processe. Sovetskoe gosudarstvo i pravo-The Soviet state and law, 6, 80-86. [in Russian].

6. Kaminskaya, V. I. (1948) Uchenie o pravovyh prezumpciyah v ugolovnom processe. AN SSSR. [in Russian].

7. Kardanec, A. V. (2002) Preyudicii v rossiyskom prave. Problemy teorii I praktiki. Candidate's thesis. Nizniy Novgorod. [in Russian].

8. Kryminalnyi protsesualnyi kodeks Ukrayiny vid 13.04.2012. (2012). URL: https:/ / zakon.rada.gov.ua/laws/show/4651-17 [in Ukrainian].

9. Popov, S. V. (2007) K voprosu o sistemnom podhode k issledovaniyu pravovyh preyudiciy. Yuridicheskaya tehnika- Legal technique, 1, 208-210. [in Russian].

10. Pro sudoustriy i status suddiv: Zakon Ukrainy vid 02.06.2016 r. № 1402-VIII. (2016).URL: https://zakon.rada.gov.ua/laws/show/1402-19. [in Ukrainian].

11. Strogovich, M. S. (1947) Ucheniye o materialnoy istine v ugolovnom processe. AN SSSR. [in Russian].

12. Shtutin, Y. L. (1956) Predresheniya (preyudicii) v sovetskom grazdanskom processe. Sovetskoe gosudarstvo i pravo- The Soviet state and law, 5, 58-67. [in Russian].

Стаття надіӥшла до редколегї 20.11.2019

Шилин Д. В., кандидат юридических наук, доцент, доцент кафедры уголовного процесса Национального университета «Одесская юридическая академия» (г. Одесса, Украина)

\section{ОБЩИЕ ВОПРОСЫ ИСПОЛЬЗОВАНИЯ ПРЕЮДИЦИИ В УГОЛОВНОМ ПРОИЗВОДСТВЕ}

Статья посвящена исследованию вопросов, связанных с пределами использования преюдиции в уголовном производстве, а также определению путей 
усовершенствования механизма использования преюдиции в уголовном производстве и разрешению спорных ситуаций, которые возникают при использовании преюдиций в уголовном процессе. Раскрыт механизм действия преюдиции в уголовном процессе. Определены направления разрешения преюдициальных коллизий при производстве по уголовному делу.

Ключевые слова: преюдиция, доказывание в уголовном процессе, преюдициальность, юридические факты, обязательность судебных решений.

Shylin D.,

Candidate of Law, Associate Professor, Associate Professor at the Department Criminal procedure of the National University "Odessa Law Academy"

(Odessa, Ukraine)

\section{GENERAL ISSUES OF USE OF PREJUDICE IN CRIMINAL PROCEDURE}

The article is devoted to the study of issues related to the limits of the use of prejudice in criminal proceedings. The procedural role of prejudice is manifested in procedural economy, since it makes it possible to use previously established facts and circumstances without repeatedly carrying out all stages of proof. However, it should be noted that prejudice may not be accepted by the court if it contradicts the judge's internal conviction. For the proper application of prejudice, it is necessary to strike a balance between it and the internal conviction of the subject of proof, which can be expressed in the manner established by the legislator to refute prejudice. The importance and necessity of applying the decisions of other courts to the court, which resolves the case essentially within the criminal proceedings, is investigated. According to the author, the significance of prejudice also lies in the increased responsibility of judges, as it contributes to the issuance of legal and reasonable decisions that concern not only the rights and interests of the parties to criminal proceedings, but may further affect the observance of the rights and interests of other persons, which depend on facts established in this decision. Prejudice encourages judges to make decisions that are appropriately motivated and characterized by clarity, clarity, persuasiveness of the arguments presented in the motivating and resolutive parts of the decision. It should be noted separately that prejudice cannot establish the guilt of a person. The article identifies ways to improve the mechanism for using prejudice in criminal proceedings. Resolution of disputes that arise when using prejudices in criminal proceedings. The mechanism of action of prejudice in criminal proceedings is disclosed. The directions of resolving prejudicial conflicts in criminal proceedings are determined.

Key words: prejudice, evidence in criminal proceedings, prejudice, legal facts, binding judgments. 